Journal of Biological Sciences 8 (8): 1289-1297, 2008

ISSN 1727-3048

(C) 2008 Asian Network for Scientific Information

\title{
Effects of Livestock Grazing on Vegetation Composition and Soil Moisture Properties in Grazed and Non-Grazed Range Site
}

\author{
${ }^{1} \mathrm{~F}$. Amiri, ${ }^{2} \mathrm{Ali}$ Ariapour and ${ }^{3} \mathrm{~S}$. Fadai \\ ${ }^{1}$ Islamic Azad University, Bushehr Branch, Iran \\ ${ }^{2}$ Islamic Azad University, Brojerd Branch, Iran \\ ${ }^{3}$ Department of Natural Resources, Tehran University, Iran
}

\begin{abstract}
Studies of vegetation and soil dynamics on grazed and non-grazed rangelands are important prerequisites for improving range management. For this reason, the effects of excluding grazing animals for 26 years were studied on vegetation and soil dynamics at two rangeland condition sites (enclosure and exclosure) in Isfahan province, Iran. The vegetation cover and edaphic characteristics were studied simultaneously in both grazed and non-grazed range sites. In this study vegetation characteristics, as well as vegetation floristic, canopy cover, plant density, botanical composition, plant biodiversity and soil moisture infiltration were recorded during the grazing seasons of 2006 to 2007. Vegetation characteristics, in particular vegetation cover and plant density, differed significantly between the non-grazed (enclosed) and grazed sites and increased significantly in the non-grazed range site. The vegetation cover in the non-grazed site consisted mainly of class I and II plants while class III plants predominated in the grazed site. There was no significant difference in the botanical composition of the two areas. There was a significant increase in Gramineae in the enclosure site compared to the surrounding grazed site, but there was a considerable decrease in forb species. We also observed a significant decrease in soil infiltration rates in the grazed range site compared to the enclosed range site. Litter content was higher inside and exposed bare soil greater outside the enclosure. Infiltration rates were higher in the enclosed area than in the grazed exclosure area throughout the grazing season. A comparison of vegetation and soil infiltration within the enclosure showed that vegetation condition and soil infiltration were good and that removal of grazing animals, as in the enclosure, causes an improvement in rangeland condition in this region.
\end{abstract}

Key words: Livestock grazing, vegetation composition, soil moisture, enclosure, exclosure, plant diversity

\section{INTRODUCTION}

Livestock and plants interact constantly within rangeland ecosystems (McNaughton, 1979). Overgrazing pressure that accompanies an increase in the human and livestock populations causes a significant reduction in plant growth vigor and reproduction ability and poor establishment of valuable plants which leads in turn to a changed botanical composition and soil moisture properties (Heitschmidt et al., 1987). There is also a reduction in the density of class I (highly preferred palatable plants for livestock grazing) category range plants (Brand and Goetz, 1986; Warren et al., 1986). According to standard definitions, an enclosed site is that part of the rangeland which is totally closed to animal grazing and is used for ecological and biological studies. Long term enclosures are used to preserve genetically diverse plants reserves, succession and natural development of range plant communities. Seed production and protection of class I range plants and endangered species are the other goals of range enclosure.

Soil moisture holding capacity plays an important role in vegetation establishment and growth in rangelands. Soil structure as well as management practices on rangeland ultimately influence the root development and re-establishment of range plants (Chaichi et al., 2005).

Enhancement of plant reproduction is virtually guaranteed if grazing pressure is reduced within a grazing system, along with development of water resources. When the rangeland was grazed by livestock within a rangeland enclosure experiment, the diversity of species of class I range plants was reduced. Plant diversity increased only in moderately grazed sites (Dadkhah and Gifford, 1980). In a four year range exclosure experiment in semi-arid rangelands, McGinty et al. (1979) observed no significant difference in botanical composition or biomass production between the grazed and non-grazed sites.

Corresponding Author: Fazel Amiri, Islamic Azad University, Bushehr Branch, Iran 
However, there were significant improvements in the palatability and growth patterns of different range plants through being within a range enclosure. In a five year study, Warren et al. (1986) significantly increased the incidence of class I, II (moderately preferred in terms of palatability) and III (unpalatable) plants by 138.8, 120.8 and $51.5 \%$, respectively, along with a $62 \%$ increase in total vegetation cover.

The grazing of rangeland plants by livestock has concurrent adverse consequences in terms of the soil surface becoming compacted, which in turn adversely affects the infiltration of moisture into the soil. In most cases the present range condition is a consequence of previous management (Ferrero, 1991).

Many researchers have reported the destructive effects of high intensity grazing on soil physical properties. However, the severity of grazing impacts is determined by range and soil condition (Johnston et al., 1971; Severson and Debano, 1991; Sun and Liddle, 1993; Curtis and Wright, 1993). Soil organic matter content is one of the most important soil components, along with stabilizing soil structure and improving infiltration rate. Intensive grazing reduces soil organic matter, compacts the soil surface layer and ultimately increases surface runoff (Faizul et al., 1995). McCalla et al. (1984) and Thurow et al. (1986) concluded that the biomass of the available vegetation plays an important role in modifying the soil infiltration rate of rangeland. Weitz and Wood (1986) reported that the amount of water infiltrated in the soil under short term grazing was half of the amount infiltrated under long term grazing. They concluded that this was because of a severe reduction in vegetation cover and expansion of bare ground.

Overgrazing is a major problem in most of the rangelands in Iran. An experiment was conducted in the mountainous Hanna rangeland region located in the southeast part of Isfahan, Iran, so as to understand the soil response to different grazing intensities and its effect on soil moisture penetration and range vegetation dynamics.

\section{MATERIALS AND METHODS}

The Hanna rangeland experiment has an area of approximately 500 hectares and is located $140 \mathrm{~km}$ southeast of Isfahan, Iran (Fig. 1) $\left(51^{\circ} 38^{\prime}-51^{\circ} 50^{\prime} \mathrm{E}\right.$ and

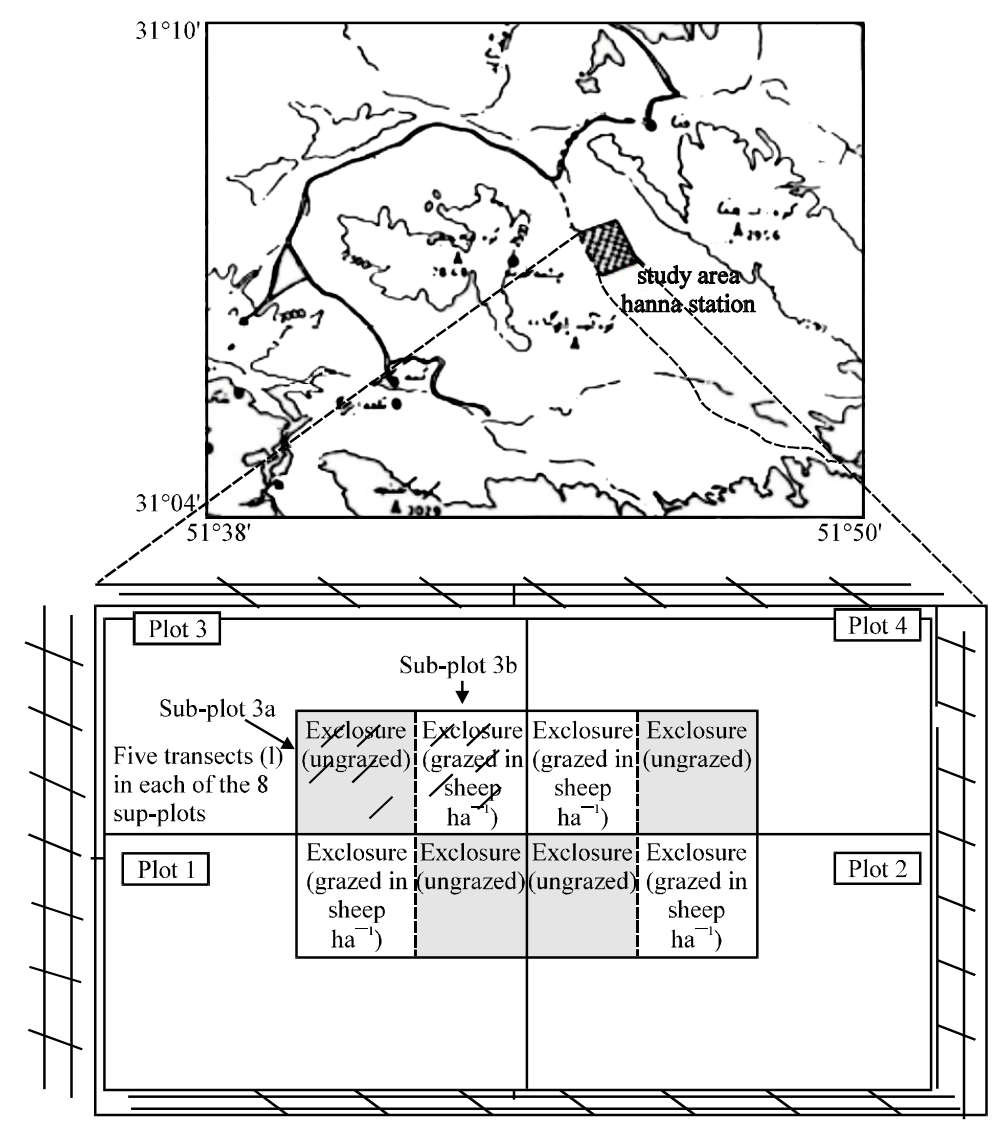

Fig. 1: Location of the study area and experimental design 
J. Biol. Sci., 8 (8): 1289-1297, 2008

Table 1: List of floristic species in grazed and ungrazed in 2006 and 2007 at Hanna rangelands, northeast Isfahan, Iran

\begin{tabular}{|c|c|c|c|c|c|}
\hline Species & Palatability class & Life form & Species & Palatability class & Life form \\
\hline Achillea aucheri & III & PF. & Hordeum bulbosum & III & PF. \\
\hline Agropyron tricophrum & I & PG. & Hordeum violaceum & II & $\mathrm{PF}$. \\
\hline Agropyron interme dium & I & PG. & Iris sp. & III & PF. \\
\hline Artimisia aucheri & III & Sh. & Lepudum sp. & II & PF. \\
\hline Astragalus cyclophylus & I & PF. & Noce a mucronata & III & Sh. \\
\hline Astragalus sp. & I & PF. & Onobrychis melonotricha & I & PF. \\
\hline Bromus tomentalus & I & PG. & Phlomis olivieri & III & PF. \\
\hline Bromus tectorum & II & PG. & Poa bulbosa & III & PF. \\
\hline Cousinia bachtiarica & III & PF. & Scariola orientalis & $\Pi$ & PF. \\
\hline Cousinia cylindrocea Boiss. & III & PF. & Sersium sp. & III & PF. \\
\hline Dactylis glomerata & II & PG. & Silen arbescula & II & PF. \\
\hline Daphne mucronata & III & BT. & Stachys inflate & II & PF. \\
\hline Echinops cephalotes & III & PF. & Stipa barbata & III & PG. \\
\hline Eryngium billordieri & II & PF. & Taraxacum polycphalum & II & PF. \\
\hline Euphorbia sp. & III & PF. & Tragopagon collinus & II & PF. \\
\hline Eurotia ceratoides & II & Sh. & Trignella sp. & II & PF. \\
\hline Festuca ovina & I & PG. & Tulipa sp. & III & PF. \\
\hline
\end{tabular}

PF: Perennial Forbs, SH: Shrub, BT: Bush Tree, PG: Perennial Grass

$\left.31^{\circ} 04^{\prime}-31^{\circ} 10^{\prime} \mathrm{N}\right)$. The climate is temperate semi-arid with an average annual precipitation of $316 \mathrm{~mm}$ and a mean annual temperature of $14.5^{\circ} \mathrm{C}(1980-2007)$. Most of the annual precipitation occurs during winter (December-February) and spring (March-May) comprising 42.6 and $29.7 \%$ of the annual total, respectively. The soil profile is deep with a medium texture of silty loam having a good granulated structure. The non-grazed range site was closed to grazing for 26 years (Anonymous, 2006). Data were collected for two years, 2006 and 2007, from grazed and non-grazed rangeland sites, adjacent to a non-grazed range with similar climatic and soil conditions.

The primary grass species represented in the area are Agropyron intermedium, Bromus tomentellu, Agropyron sp., Bromus tectorum, Poa bulbosa, Stipa barbata, Festuca ovina and Dactylis glomerata. The primary forbs species are Achillea aucheri, Astragalus cyclophylus, Cousinia bachtiarica and Hordeum bulbosum (Table 1).

Sheep have been herded in the study area of rangeland by nomads for meat and milk production for over 100 years. Continuous stocking is practiced extensively from May through to September (the grazing season) every year. Watering points are available in different parts of the rangeland as natural springs and streams. Mean stocking rate varies in different parts of the rangeland according to the available biomass and water supply, as well as whether or not the different tribes can obtain permission from the government authorities. The mean stocking rate on most of the area in a normal season is one sheep per hectare during the grazing season (late May to late September). However, the number of sheep grazing in different parts of the rangeland differs according to the area allocated to each tribe.

Sampling procedure: The study area was sub-divided into grazed and non-grazed plots according to grazing history and condition: an ungrazed area (enclosed) has been exempted from livestock grazing for 26 years (1981-2007). Stocking rates for the moderately and heavily grazed areas were 1 and $>3$ sheep hectare, respectively, for the 26 years. All plots had similar climatic conditions, topography, soil texture and parent materials.

Vegetation cover was measured in both the grazed and non-grazed areas. The percentage of vegetation cover and its components were measured, as well as bare ground, at the beginning and end of the grazing season. Transects were $100 \mathrm{~m}$ long and 10 quadrats were recorded for each (Daubenmire, 1959). Five transects were set up in each sampling area (one per strata) and ten quadrats were randomly assigned per transect to measure the percentage vegetation cover as well as the frequency of individual species and vegetation groups (grasses, forbs and shrubs). Plant density, vegetation cover and a floristic list of botanical composition of class I, II and III plants were measured for two dominant vegetation types in quadrats in both the grazed and un-grazed sites. The proper number of quadrats in each site was calculated by the following Eq. 1:

$$
\mathrm{N}=\frac{\mathrm{t}^{2} \times \mathrm{s}^{2}}{(\overline{\mathrm{x}} \times \mathrm{k})^{2}}
$$

Where:

$\mathrm{N}=$ Number of essential samples

$\mathrm{t}=$ The $\mathrm{t}$ student value with (n-1) and $=5 \%$

$\mathrm{s}=$ Standard variation

$\overline{\mathrm{x}}=$ Mean vegetation cover

$\mathrm{n}=$ Primary sample number

$\mathrm{k}=$ Precision coefficient $(10 \%)$ (Bonham, 1989)

In order to determine species diversity, Shannon's diversity index (Shannon-Weaver, 1963) was measured based on total cover percentage in both the grazed and 
un-grazed sites using MVSP Software. Equation 1 and 2 was used to determine plant diversity:

$$
\begin{gathered}
\mathrm{J}=\frac{\mathrm{H}^{\prime}}{\mathrm{H}_{\max }^{\prime}}=\frac{\sum_{i=1}^{s} \mathrm{P}_{\mathrm{i}} \operatorname{LnP} \mathrm{P}_{\mathrm{i}}}{\operatorname{LnS}} \\
\mathrm{H}^{\prime}=-\sum_{i=1}^{s} \mathrm{P}_{\mathrm{i}} \operatorname{Ln} \mathrm{P}_{\mathrm{i}}
\end{gathered}
$$

where, $\mathrm{P}_{\mathrm{i}}$ is the ratio of one species to all, $\mathrm{LnP}_{\mathrm{i}}$ is the $\log$ of the species ratio and $\mathrm{S}$ is the total number of species (Shannon-Weaver, 1963).

In Shannon's diversity index, the bigger the number the more diversity. The bigger values of J demonstrate that the distribution of species is more consistent in the frame, so that we can conclude that it is satisfactory evidence of the suitable propagation of plant species.

All the measurements were repeated for the two years, 2006 and 2007. Soil moisture holding capacity was measured in two rangeland sites of grazed and non grazed (enclosure area). The Soil infiltration rate was measured using a double ring method at the start (from early May) and the end of the grazing season (early September). All the measurements were taken in both 2006 and 2007. Treatments were arranged in split plots in time and location and the data were analyzed using a Completely Randomized Block Design with five replications. To eliminate the effect of the year, a compound analysis of variance was run for the two years using MStatC statistical software.

\section{RESULTS}

Vegetation change: There was significantly more vegetation cover in the enclosure than in the grazed area (Table 1). Percent vegetation cover and botanical composition of class I plants in the non-grazed treatment differed significantly from the grazed treatment, but there was no significant difference between the treatments in terms of the vegetation cover of class II plants (Table 2).

There was a significant difference between the class I plant density in the grazed and non-grazed range sites (Fig. 2). The population and density of class I range plants were enhanced in the rangeland enclosure as a consequence of providing a better opportunity for the reproduction and establishment of those species in non-grazed range sites. In grazed areas the class II range plants had a better opportunity because of grazing pressure to develop and increase their population (Fig. 3).

The percent of biomass growth of class I in the grazed treatment was significantly reduced compared with class III, which could be explained by heavy grazing, loss
Table 2: Analysis of variance for vegetation cover rate in un-grazed and

\begin{tabular}{|c|c|c|c|c|}
\hline Treatment & $\mathrm{df}$ & SS & MS & $\mathrm{F}$ \\
\hline $\begin{array}{l}\text { Total vegetation cover between } \\
\text { un-grazed and grazed areas }\end{array}$ & 1 & 6903.1 & 6903.1 & $78.18^{* * * *}$ \\
\hline Error between samples & 70 & 6180.8 & 88.3 & - \\
\hline Sum & 71 & 13083.9 & - & - \\
\hline
\end{tabular}
grazed areas

***: Significant difference $(\mathrm{p}<0.01)$

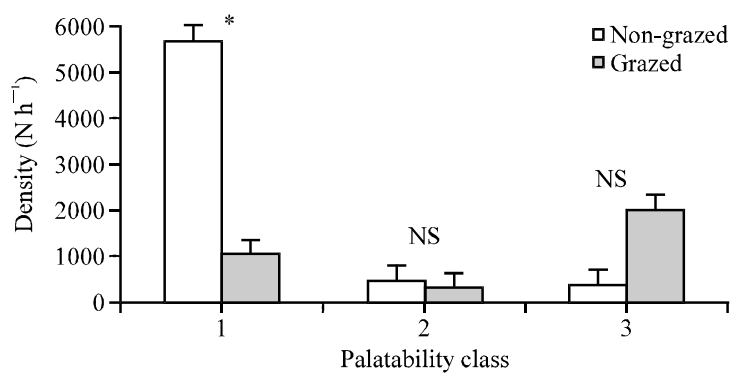

Fig. 2: Plant density of palatability class in non-grazed and grazed areas. *: Significant difference $(\mathrm{p}<0.01)$, NS: No difference $(p<0.01)$

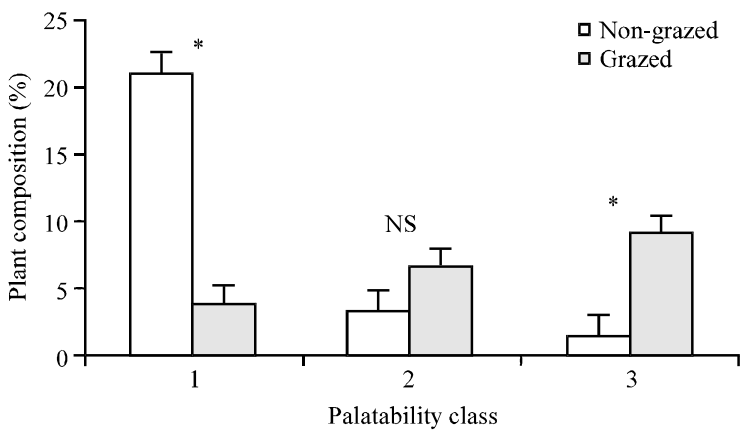

Fig. 3: Plant composition of palatability class in nongrazed and grazed areas. *: Significant difference $(p<0.01)$, NS: No difference $(p<0.01)$

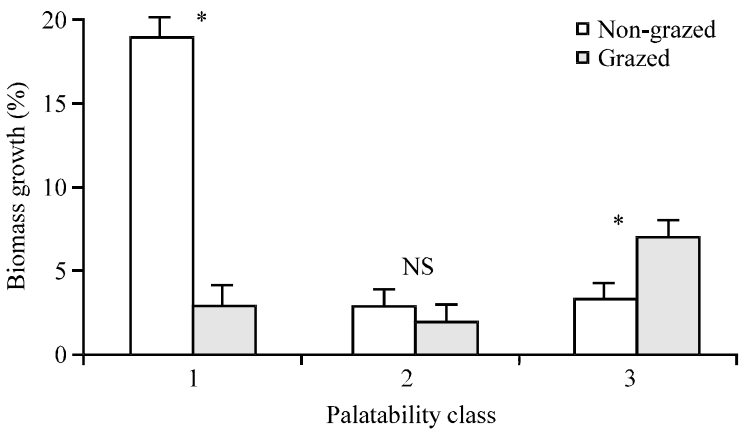

Fig. 4: Biomass growth rate in non-grazed and grazed areas. *: Significant difference $(\mathrm{p}<0.01)$, NS: No difference $(\mathrm{p}<0.01)$

of soil humus due to water erosion, livestock trampling and lack of seed resources for natural re-vegetation (Fig. 4). 
J. Biol. Sci., 8 (8): 1289-1297, 2008

Table 3: Vegetation cover rate in non-grazed and grazed areas

\begin{tabular}{lcccrr}
\hline Palatability class & $\begin{array}{c}\text { Vegetation cover in } \\
\text { non-grazed (\%) }\end{array}$ & $\begin{array}{l}\text { Vegetation cover } \\
\text { in grazed (\%) }\end{array}$ & $\begin{array}{l}\text { Vegetation composition } \\
\text { in non-grazed (\%) }\end{array}$ & \multicolumn{2}{c}{$\begin{array}{l}\text { Vegetation composition } \\
\text { in grazed (\%) }\end{array}$} \\
I & $1.8 \pm 56.9$ & $21.2^{* * *}$ & 78.7 & $40.3^{* * *}$ & T-value \\
II & $2.9 \pm 12$ & $10.8^{\mathrm{NS}}$ & 16.6 & $20.5^{\mathrm{NS}}$ & 25.21 \\
III & $1.1 \pm 3.4$ & $20.6^{* *}$ & 4.7 & $39.2^{* * *}$ & 5.76 \\
Total & 72.3 & 52.6 & 100.0 & 100.0 & 42.10 \\
\hline
\end{tabular}

**: Significant difference $(\mathrm{p}<0.01),{ }^{\text {NS }}$ : No significant difference $(\mathrm{p}<0.01)$

Table 4: Vegetation composition (percentage) of rangeland in enclosure and exclosure in 2006 and 2007 at Hanna rangelands, northeast Isfahan, Iran

\begin{tabular}{|c|c|c|c|c|c|c|c|c|}
\hline \multirow[b]{4}{*}{ Range site } & \multicolumn{8}{|c|}{ Grazing period } \\
\hline & \multicolumn{4}{|c|}{ May ( early grazing) } & \multicolumn{4}{|c|}{ September (end of grazing) } \\
\hline & \multicolumn{4}{|c|}{ Vegetation composition (\%) } & \multicolumn{4}{|c|}{ Vegetation composition (\%) } \\
\hline & Grass & Forbs & Litter & Bare ground & Grass & Forbs & Litter & Bare ground \\
\hline Un-grazed area (enclosure) & $42.8^{\mathrm{ab}}$ & $29.5^{b}$ & $17.6^{b}$ & $8.7^{\mathrm{c}}$ & $12.1^{c}$ & $10.1^{\mathrm{c}}$ & $69.1^{\mathrm{a}}$ & $10.1^{\mathrm{c}}$ \\
\hline Grazed area (exclosure) & $15.4^{b}$ & $36.8^{\mathrm{ab}}$ & $15.6^{b}$ & $32.2^{b}$ & $3.1^{\mathrm{c}}$ & $18.7^{\mathrm{b}}$ & $8.2^{\mathrm{c}}$ & $70.0^{\mathrm{a}}$ \\
\hline
\end{tabular}

Within columns and rows for each parameter and treatment, means with the same letter are not significant at $p<0.05$

Table 5: Analysis of variance for species diversity in un-grazed and grazed areas

\begin{tabular}{lclll}
\hline Variance source & df & SS & MS & F-value \\
\hline Species diversity between Un-grazed and grazed areas & 1 & 0.0003 & 0.0003 & $0.1557^{\mathrm{NS}}$ \\
Error between samples & 50 & 0.0187 & 0.0003 & - \\
Sum & 51 & 0.0220 & - & - \\
\hline
\end{tabular}

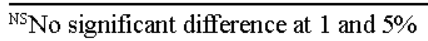

Table 6: Soil moisture of rangeland in both the enclosure and exclosure in 2006 and 2007 at the Hanna rangelands, northeast Isfahan, Iran

\begin{tabular}{|c|c|c|c|c|c|c|c|c|c|}
\hline & \multicolumn{2}{|l|}{ Year } & \multicolumn{2}{|c|}{ Grazing treatment } & \multicolumn{5}{|c|}{ Grazing period } \\
\hline & 2006 & 2007 & Ungrazed area & Grazed area & May & June & July & August & September \\
\hline Soil moisture (\%) & $6.8^{a}$ & $5.5^{b}$ & $6.5^{\mathrm{a}}$ & $5.3^{b}$ & $7.3^{\mathrm{a}}$ & $6.7^{\circ}$ & $6^{c}$ & $5.3^{\mathrm{d}}$ & $6.1^{\mathrm{c}}$ \\
\hline
\end{tabular}

Within columns for each parameter and treatment, means with the same letter are not significantly different at $\mathrm{p}<0.05$

The average vegetation cover in the un-grazed treatment was $72.3 \%$ in early May, of which more than half $(37.6 \%)$ was associated with the cool season grasses, whereas the rest was comprised of forbs. The percentage of vegetative cover in the enclosure area declined to $22.2 \%$ in the final days of September, which marks the end of the grazing season. At this time the grass population within the sward declined drastically insofar as the amount of grass cover declined from 42.8 to about $12.1 \%$ (Table 3 ). The percentage of vegetative cover within the grazed zone was $21.8 \%$ in the last days of September, comprising 3.1\% Millet and $18.7 \%$ graminaceous broadleaf species (Table 4). By the end of the grazing period, the grass component of the vegetation cover in all areas had decreased significantly (Table 4). The percentages of bare ground in the un-grazed and grazed areas in early May were 8.7 and $32.2 \%$, respectively, this increasing to 10.1 and $70 \%$ by the end of the grazing season. The increase was statistically significant in the grazed treatment, but not in the un-grazed treatment. The results of the present experiment support the positive effect of excluding grazing animals on vegetation development in the semiarid rangelands of Iran.
Species diversity: The mean diversity indices in the grazed and un-grazed sites were $\mathrm{H}=0.8$ and $\mathrm{H}=0.87$, respectively. However, these values were not significantly different (Table 5).

Infiltration rate. Infiltration rate varied by year, grazing treatments, grazing period and their interactions (Table 6). The mean soil moisture content was significantly higher in both rangeland sites in 2006 compared with 2007. It decreased under grazing pressure in both years, although less so in 2007 , which was a drier year. Soil moisture decreased in both years as the grazing season proceeded until September, when soil moisture increased (Table 6).

The infiltration rate followed a decreasing trend from early in the grazing season (early May) until the end of the grazing season (early September) (Table 7). In all experimental sites the infiltration rate during the first $5 \mathrm{~min}$ of water application was higher than the rest of the measuring period of $90 \mathrm{~min}$.

The rate of soil infiltration decreased during the initial $5 \mathrm{~min}$ in $0.6 \%$ of grazing situations compared with the same time in the selected enclosed area. This was because of increased exposure of bare soil under grazing. 
J. Biol. Sci, 8 (8): 1289-1297, 2008

\begin{tabular}{|c|c|c|c|c|c|c|c|c|c|c|c|c|}
\hline \multirow[b]{4}{*}{ Range site } & \multicolumn{12}{|c|}{ Infiltration rate $\left(\mathrm{mm} \mathrm{min}^{-1}\right)$} \\
\hline & \multicolumn{6}{|c|}{ May (early grazing) } & \multicolumn{6}{|c|}{ September (end of grazing) } \\
\hline & \multicolumn{6}{|c|}{ Measuring time } & \multicolumn{6}{|c|}{ Measuring time } \\
\hline & 1 & 5 & 10 & 30 & 60 & 90 & 1 & 5 & 10 & 30 & 60 & 90 \\
\hline Un-grazed area (Enclosure) & $20^{\mathrm{a}}$ & $8.0^{\circ}$ & $5.0^{d}$ & $4.5^{\mathrm{d}}$ & $4.0^{\mathrm{d}}$ & $3.5^{\mathrm{d}}$ & $12.0^{\mathrm{a}}$ & $7^{\mathrm{c}}$ & $5.0^{\mathrm{d}}$ & $4.5^{\mathrm{d}}$ & $3.5^{\mathrm{e}}$ & $3.0^{f}$ \\
\hline Grazed area (Exclosure) & $12^{b}$ & $4.5^{\mathrm{d}}$ & 3. $0^{\mathrm{d}}$ & $2.0^{\circ}$ & $1.5^{\mathrm{ef}}$ & $0.7^{\mathrm{f}}$ & $9.5^{\mathrm{b}}$ & $4^{\mathrm{d}}$ & $2.7^{\mathrm{e}}$ & $1.7^{\mathrm{f}}$ & $1.1^{\mathrm{f}}$ & $0.5^{\mathrm{g}}$ \\
\hline
\end{tabular}

Within columns and rows for each parameter and treatment, means with the same letter are not significant at $\mathrm{p}<0.05$

\section{DISCUSSION}

Vegetation change: Over half of the canopy cover within an enclosure was made up of plants that were either increasing in density, whereas there was little or negligible change in plant numbers outside the exclosure where $95 \%$ of the plants were undesirable invaders. More desirable species were present inside the protective enclosure. Vegetative cover in the enclosed area declined significantly in the final days of September, concurrent with the end of the grazing season. At this time the grass population and cover declined dramatically as the plants matured and senesced so that the vegetative cover in the grazed plots at the end of the grazing season was only $21.8 \%$, of which $3.1 \%$ were grasses and $18.7 \%$ were broadleaved forbs. The importance of the percentage of broadleaf species cover in the grazed situation compared with in the non-grazed enclosure is that the broadleaf species are dormant at the beginning of the grazing season, are actively growing in the middle of the season and reach maturity towards the end of the grazing season. Whereas cold season grass species are able to survive the cold winter period, they reach their maximum growth rate early in the grazing season.

Akbarzadeh et al. (2007) reported that after 24 years livestock exclusion in Kuhrang, total canopy cover within an enclosure was higher than on the outside. There was a higher density of grasses and forbs within the enclosure than outside, but shrubs were not significantly different.

Mirza Ali et al. (2006) studied the effect of enclosure on the vegetative cover and surface soil of salty pastures in the Golestan province of Iran in which Millet over several years and forbs in one year accounted for most of the vegetative cover outside the enclosure. Johnson et al. (1971) observed long term grazing to have a significant effect on vegetative cover, this being less under light grazing (1 animal unit per hectare) than under heavy grazing intensity ( 2.5 animal units per hectare) in which the amount of forbs and shrubs increased, consistent with the findings of our study.

Page et al. (1999) observed that grass cover in Acacia-dominated savannah woodlands was negatively related to the intensity of grazing, whereas in a non- grazed enclosure the palatable grasses dominated the mixture. Dormaar et al. (1989) observed that in grasslands of semi-arid regions, grazing causes a decline in the proportion of grass species. Chaichi et al. (2005) investigated the effect of trampling of soil on changes of vegetative cover and in the physical characteristics of the soil in Lar rangeland and found that the grass-green cover decreased from 38 to $9.5 \%$ at the end of the grazing period, due to a cessation of the growth of certain herbaceous species. Over a number of years the herbage cover declined-in grass, green plant species and broad leaf herbs like thyme, with a concurrent increase in other broad leaf herbs over this period.

Present observations correspond with those of Chaichi et al. (2005). who observed the percentage of bare soil in an enclosure at the beginning of a grazing season to decrease from 10.1 to $8.7 \%$ by the end of a grazing season. The reason for this in this study was an increase in dead litter in the region from $17.6 \%$ at the beginning to $69.1 \%$ at the end of grazing season (Table 4). Therefore the presence of dead litter is the most important protective factor of the soil in the latter days of September.

In present study we found that the density of class I species differed significantly according to whether the site was grazed or non-grazed, even though this difference did not occur in the case of class II species. In other words the proportion of palatable plants was able to increase in the enclosure because the plants were able to flower, seed set with new seedlings germinating.

In a survey of the effect of grazing in America's coastal regions, Bellows (2003) reported that grazing led to trampling of the surface soil and a decrease in plant density and herbage cover associated with more intense soil erosion and a decrease in plant production and establishment. Vahabi et al. (1997) showed that after 5 years, the intensity of herbage in the class I, II and III palatability classes increased in protected pastures by $138.8,120.8$ and $51.5 \%$, respectively compared with grazed pastures, accompanied by a $62 \%$ increase in total vegetative cover. The reason for the differences between their work and ours may be related to differences in topography and environmental conditions, the type and percentage of vegetative cover and the duration of the 
enclosure in the two locations. Being in a non-grazed enclosure allows the development of a different herbage structure of palatable species compared with when they are regularly grazed. In general the percentage of class I plant species decreased from $78.7 \%$ in an enclosure to $40.5 \%$ under grazing conditions. In other words the enclosure provided better conditions for the establishment of palatable species. Under grazing, a significant percentage of herbage structure is assigned to relatively unpalatable or inedible species (class III), these being comprised mainly of invasive weeds and plants with thorns. In general, the percentage of these species within the sward increased from $4.7 \%$ in a non-grazed enclosure to $39.2 \%$ under typical grazing conditions. The percentage of class II species plants did not vary significantly between enclosed and grazing situations at the beginning of the grazing season. Grazing pressure has its main effect on palatable species (class I). Under light and moderate grazing the broad leaf species can attain the required opportunity for better procreation and establishment so as to achieve a greater share of the sward structure. But at the end of the grazing season the reason for the reduction in the proportion of palatable species within the botanical composition of the sward. Grazing pressure favored less palatable species (class II) and at the end of grazing season the percentage of class II species accounted for less of the botanical composition. By this stage the percentage of class III plants increased from $4.7 \%$ in a non-grazed enclosure to $39.2 \%$ under grazing because of the lack of palatability of these plant species. Grazing pressure impacts on edible plants which need the land to be spelled from grazing so that and these species have an opportunity to become established. Jalilvand et al. (2007) showed that more grasses and forbs present in the ungrazed area and shrubs increased with an increases in grazing intensity. Ungrazed area also had more species of palatability classes of I and II but more species of class III and unpalatable species were found in grazed area.

Species diversity: The lack of a significant difference in vegetation diversity between the non-grazed and grazed areas contrasts with a similarly designed experiment by Warren et al. (1986) with range sites grazed by cattle, in which 13 important range species decreased in density after five years. This is while the density of class I, II and III plants increased by $138.8,120.8$ and $51.5 \%$ in enclosed range sites compared to grazed ones. In an experiment conducted in Argentina, Passera and Borsetto (1996) noted that the reproduction of palatable perennial grass plants in plots closed to grazing was much faster than those that were grazed. Kakinuma and
Takatsuki (2008) investigated the change in plant communities by grazing in northern Mongolia and observed that species diversity and biomass of forb decreased with increasing grazing intensity. However, thin plants grass did not decrease in grazing intensity. In semi-arid rangelands of Iran the succession in the trend of vegetation cover without human intervention is gradually moving to tall perennial grass plants accompanied by palatable forbs.

Soil Infiltration: The decline in infiltration rates from the beginning to the end of the grazing seasons in both selection areas and grazing regions clarified how soil responds to intensive stock grazing. In early May, at the beginning of the grazing season, the rate of soil infiltration in the first five minutes declined by $62.5 \%$ from 12 to $4.5 \mathrm{~mm} \mathrm{~min}^{-1}$. By the end of the grazing season at the end of September the infiltration rate had declined to around $58 \%$ for the grazing region. This was due to compaction of the soil surface layer and damage to soil structure due to grazing in previous years. The lack of vegetation and organic materials was accompanied by a decrease in infiltration of around $4 \%$ at the beginning of the grazing season compared with the non-grazing region.

The results highlighted that the compaction from livestock trampling likely contributed soil surface and botanical composition and vegetation impacts on the decreasing soil infiltration rate. These results are compatible with the findings of Mapfumo et al. (2000). Chaichi et al. (2005) reported that soil infiltration rate in stock grazing region in the first grazing season decreased from 12 to $4 \mathrm{~mm} \mathrm{~min}^{-1}$ (decreasing 67\%). Also Faizul et al. (1995) identified that grazing results in a decrease in water infiltration into the soil and a compaction of the soil surface layer along with a decrease in the soil organic material. Naeth et al. $(1991,1995)$ with surrey of grazing impact on vegetation and soil infiltration rate clarified that the disturbed topsoil structure as a result of the effects from trampling by grazing animals is a primary reason for lower water infiltration.

Warren et al. (1986) reported that the rate of infiltration of water through the profile of rangeland soils declines under grazing along with an increase in soil compaction. They also identified that an increase in livestock numbers resulted in damage through trampling, particularly when the soil is wet and prone to pugging. Belsky and Blumental (1997) surveyed the impacts of stock grazing on vegetation and soil rate in alpine forest region in the west of USA and reported that stock grazing in these regions resulted in a decrease in surface cover, compaction of soil, decreasing water infiltration in the soil 
and increasing soil erosion. Laycock and Conrad (1967) observed a significant relationship between increased livestock trampling, decreased soil infiltration and increased soil compaction, although it is not a linear one. Perevolotsky (1994) studied the impacts of grazing on conservation operation and the reclamation of natural resources in Israeli semi-arid areas and identified that over-grazing affects land cover, runoff and soil erosion, soil moisture infiltration and a decline and removal of nutrients from the grazing system.

The pressure of livestock grazing and overall utilization of rangelands has caused soil and vegetation degradation in many natural rangelands of Iran. Present study has demonstrated that grazing prevention is an important means of rehabilitating and renovating rangelands. To improve the vegetation cover in moderately grazed areas, the grazing of rangelands by livestock needs to be restricted for at least three years before the land is then managed with a more moderate stocking density that is in accordance with the rangeland's capacity to produce. In the heavily grazed area, the vegetation cover needs to be improved by the seeding and establishment of high quality rangeland plants with grazing livestock totally prohibited until the plants become well established and reproduce through natural regeneration.

\section{ACKNOWLEDGMENT}

The authors are grateful to Dr David White of ASIT Consulting, Australia, for his suggestions and advice in the preparation of this study.

\section{REFERENCES}

Akbarzadeh, M., M.R. Moghadam, A. Jalili, M. Jafari and H. Arzani, 2007. Vegetation dynamic study of Kuhrang enclosure. Ir. J. Range Desert Res., 13: $324-336$.

Anonymous, 2006. Report of soil condition and vegetation change in Hanna Station. Isfahan, Iran.

Bellows, B.C., 2003. Managed grazing in riparian areas. National Center for Appropriate Technology, USDA. pp: 5.

Belsky, A.J. and D.M. Blumenthal, 1997. Effect of livestock grazing on stand dynamics and soils in upland forests of the interior west. Conservat. Biol., 11: 315-327.

Bonham, C., 1989. Measurement Terrestrial Vegetation. 2nd Edn., John Wiley and Sons Inc, New York.

Brand, M.D. and H. Goetz, 1986. Vegetation of exclosures in southwestern North Dakota. J. Range Manage., 39: 434-437.
Chaichi, M.R., M.M. Saravi and M. Arash, 2005. Effects of livestock trampling on soil physical properties and vegetation cover (Case Study: Lar Rangeland, Iran). Int. J. Agric. Biol., 7: 1-5.

Curtis, D. and T. Wright, 1993. Natural regeneration and grazing management a case study. Australian J. Soil Conservat., 6: 30-34.

Dadkhah, M. and G.F. Gifford, 1980. Influence of vegetation, rock cover and trampling on infiltration rates and sediment production. Water Resour. Bull., 16: 979-986.

Daubenmire, R., 1959. A canopy-cover method of vegetation analysis. Northwest Sci., 33: 43-64.

Dormaar, J.F., S. Smoliak and W.D. Willms, 1989. Vegetation and soil responses to short-duration grazing on fescue grasslands. J. Range Manage., 42: $252-256$

Faizul, B., D.M. Karlw and L. Murray, 1995. Livestock grazing impacts on infiltration rates in a temperate range of Pakistan. J. Range Manage., 46: 367-372.

Ferrero, A.F., 1991. Effect of compaction (simulating cattle trampling) on soil physical characteristics in woodland. Soil Tillage Res., 19: 319-329.

Heitschmidt, R.K., S.L. Dowhower and J.W. Walker, 1987. Some effects of a rotational grazing treatment on quantity and quality of available forage and amount of ground litter. J. Range Manage., 40: 318-321.

Jalilvand, H., R. Tamartash and H. Heyderpour, 2007. Grazing impact on vegetation and some soil chemical properties in Kojour rangelands, Noushahr, Iran. Scientific Res. J. Ir. Range Manage. Soc., 1: 53-66.

Johnston, A., J.F. Dormaar and S. Smoliak, 1971. Longterm grazing effects on fescue grassland soils. J. Range Manage., 24: 185-188.

Kakinuma, K. and S. Takatsuki, 2008. Change in plant communities by grazing in north Mongolia and land assessment of herders. 21 st International Grassland Congress and 8th International Rangeland Congress in Hohhot, 28 June-6 July, China, pp: 493-493.

Laycock, W.A. and P.W. Conrad, 1967. Effect of grazing on soil compaction as measured by bulk density on a high elevation cattle range. J. Range Manage., 20: $136-140$.

Mapfumo, E., D.S. Chanasyk, V.S. Baron and M.A. Naeth, 2000. Grazing impacts on selected soil parameters under short-term forage sequences. J. Range Manage., 53: 466-470.

McCalla, G.R., W.H. Backburn and L.B. Merrill, 1984. Effects of livestock grazing on infiltration rates: Ewards plateau of Texas. J. Range Manage., 37: $265-268$. 
McGinty, A.W., F.E. Smeins and L.B. Merill, 1979. Influence of soil, vegetation and grazing management on infiltration rate and sediment production of Edward plateau rangeland. J. Range Manage., 32: 33-37.

McNaughton, S.J., 1979. Grazing as an optimization process: Grass-ungulate relationships in the Serengeti. The Amer. Naturalist, 113: 691-701.

Mirza Ali, A., M. Mesdagei and Z. Erfanzadeh, 2006. Effect of Enclosure on soil and vegetation cover, in Shor Ghomeyshan in Golestan province. J. Agric. Natural Resour. Gorgan, 13: 194-202.

Naeth, M.A., A.W. Bailey, D.S. Chanasyk and D.J. Pluth, 1991. Water holding capacity of litter and soil organic matter in mixed prairie and fescue grassland ecosystems of Alberta. J. Range Manag., 44: 13-17.

Naeth, M.A. and D.S. Chanasyk, 1995. Grazing effects on soil water in Alberta foothills fescue grasslands. J. Range Manage., 48: 528-534.

Page, M.J., R.J.S. Beeton, J.J. Mott and D. Eldridge, 1999. Vegetation dynamics and the implication for protected area management in South-West Queensland rangeland. People and rangelands: Building the future. Proceeding of the 6th International Rangeland Congress, Townsville, Queensland, Australia, July 19-23, pp: 225-226.

Passera, C.B. and O. Borsetto, 1996. Livestock exclosure effect in a larrea cuneifolia community located in the Mendosa piedmont. Multequina, 5: 25-31.
Perevolotsky, A., 1994. Proceedings of workshop on arid lands management toward ecological sustainability. Jerusalem. pp: 145-150.,

Severson, K.E. and L.F. Debano, 1991. Influence of Spanish goats on vegetation and soils in Arizona chaparral. J. Rangeland Manage., 44: 111-117.

Shannon, C.E. and W. Weaner, 1963. The Mathematical Theory of Communications. 1st Edn., University of Ilinois Press, Urbana, pp: 117.

Sun, D. and M.J. Liddle, 1993. A survey of trampling effects on vegetation and soil in eight tropical and sub-tropical areas. Environ. Manage., 17: 467-510.

Thurow, T.L., W.H. Backburn and C.A. Taylor, 1986. Hydrologic characteristics of vegetation types as affected by livestock grazing systems: Edwards plateau of Texas. J. Range Manage., 39: 505-509.

Vahabi, M., M. Bassiri and K. Seyed Jamal, 1997. Investigation vegetation change, species composition and production yield in enclosure and exclosure ranfeland in Feridan Isfahan province. Vol. 1 pp: 59-71.

Warren, S.D., T.L. Thurow, W.H. Blackburn and N.E. Garaza, 1986. The influence of livestock trampling under intensive rotation grazing on soil hydrologic characteristics. J. Range Manage., 39: 491-495.

Weitz, M. and M.K. Wood, 1986. Short duration grazing in Central New Mexico: Effects on infiltration rates. J. Rangeland Manage., 39: 365-368. 